\title{
Peranan Curcumin terhadap Proliferasi, Apoptosis dan Diferensiasi Hepatosit Mice Balb/C yang Dipapar dengan Benzapyrene
}

\author{
Candra Rini $^{{ }^{*}}$, Edi Widjajanto ${ }^{2}$, Rm. Loekito $^{3}$ \\ ${ }^{1}$ Program Studi Biomedik Pasca Sarjana Universitas Brawijaya \\ ${ }^{2}$ Laboratorium Patologi Klinik Fakultas Kedokteran Universitas Brawijaya \\ ${ }^{3}$ Laboratorium Anatomi Histologi Fakultas Kedokteran Universitas Brawijaya
}

\begin{abstract}
Abstrak
Pengobatan neoplasma hepar belum memuaskan. Kini sedang dikembangkan pengobatan baru yang berasal dari alam, diantaranya curcumin (bahan aktif spesies Curcuma), yang dinyatakan mempunyai aktifitas anti kanker, dan penelitiannya masih dikembangkan. Tujuan dari penelitian ini adalah untuk membuktikan pengaruh anti-karsinogenesis curcumin pada proliferasi, apoptosis dan differensiasi hepatosit pada mencit yang dipapar dengan bahan karsinogen benzapyrene. Penelitian ini menggunakan 20 ekor mencit jantan (Mus musculus Outbred BABLB/C) usia 5 minggu, dibagi menjadi 4 kelompok yaitu kelompok normal, kelompok yang diinjeksi corn oil 3,2 ml tiap kgBB (i.p), kelompok dengan benzapyrene $16 \mathrm{mg}$ tiap $\mathrm{kgBB}$ dalam corn oil secara intraperitoneal (i.p), dan kelompok yang diinjeksi benzapyrene dalam corn oil secara i.p dan diberi 0,2\% curcumin dalam pakannya. Hari ke-120 mencit dikorbankan, organ hepar diperiksa secara histopatologis. Pemeriksaan proliferasi diukur dengan satuan indeks Cyclin-PCNA secara immunohistokimia. Apoptosis diukur dengan satuan indeks apoptosis, diferensiasi diperiksa dengan mengukur $\mathrm{N} / \mathrm{C}$ ratio hepatosit, menggunakan pengecatan hematoxillin-eosin. Hasil penelitian ini menunjukkan bahwa pemberian $0,2 \%$ curcumin dalam pakan mencit yang dipapar benzapyrene menurunkan indeks Cyclin-PCNA $(\mathrm{P}<0,05)$, meningkatkan indeks apoptosis $(P<0,01)$ dan menurunkan $N / C$ ratio hepatosit $(P<0,01)$ dibandingkan dengan mencit yang dipapar benzapyrene tanpa diberi curcumin. Kesimpulan penelitian ini bahwa pemberian curcumin selama periode inisiasi dan post-inisiasi terbukti memberikan efek anti kanker, ditandai dengan penurunan proliferasi, peningkatan apoptosis, dan perbaikan pola diferensiasi sel.
\end{abstract}

Kata kunci: apoptosis, benzapyrene, curcumin, hepatosit

\section{PENDAHULUAN}

Neoplasma (tumor) terutama yang bersifat ganas (kanker), diketahui masih mempunyai mortalitas yang tinggi, dan pengobatannya saat ini belum memuaskan. Mortalitas karena kanker di indonesia menduduki urutan ke-6. WHO memperkirakan kejadian kanker adalah 180 per 100.000 penduduk [1]. Hepatocellular Cell Carsinoma (HCC) adalah salah satu dari neoplasma organ dalam yang paling umum terdapat pada manusia [2,3].

Frekuensi kanker cenderung meninggi, disebabkan oleh perbaikan derajat kesehatan dan umur rata-rata harapan hidup yang meninggi sehingga makin banyak orang yang dapat mencapai usia yang lebih tua dan mudah terkena kanker (cancerous age), adanya peningkatan taraf pengetahuan tentang kebersihan sehingga kedudukan penyakit infeksi yang sebelumnya merupakan penyakit utama di Indonesia menjadi

\footnotetext{
* Alamat korespondensi penulis:

Candra Rini Hp.

E-mail : candra_rini@gmail.com

Alamat : Laboratorium Biomedik, Fakultas Kedokteran Universitas Brawijaya, Jl. Veteran, Malang, 65154
}

bergeser digantikan oleh penyakit kanker. Selain itu, peningkatan polutan, meningkatkan paparan bahan karsinogenik sehingga dapat menambah frekuensi kanker [1].

Seiring dengan perkembangan industri di Indonesia mengakibatkan tingkat pencemaran lingkungan semakin meningkat. Salah satu bahan toksik yang dihasilkan akibat proses industri tersebut diantaranya benzapyrene (BaP). Benzapyrene merupakan suatu bahan karsinogen, yang mengandung inisiator maupun promoter, tetapi BaP lebih aktif sebagai inisiator tumor [4].

Salah satu organ yang penting untuk detoksifikasi bahan bersifat toksik yang masuk dalam tubuh akibat pencemaran lingkungan tersebut adalah hepar. Hepar memiliki fungsi vital dalam detoksifikasi bahan toksik. Hal ini menyebabkan hepar menjadi sering terpapar dengan zat-zat toksik yang mengakibatkan kerusakan sel hepar. Kerusakan sel hepar dapat berakibat proliferasi sel yang berlebihan, sehingga terjadi tumor atau kanker hepar.

Perkembangan tumor dipengaruhi oleh keseimbangan antara proliferasi, apoptosis dan 
differensiasi [5]. Hal ini dapat dinilai dengan parameter biologis perkembangan tumor, antara lain melalui penilaian pada perubahan proliferasi, apoptosis, dan diferensiasi. Peningkatan proliferasi menunjukkan terjadinya peningkatan keganasan tumor. Penurunan apoptosis menunjukkan adanya kegagalan lokal dalam mekanisme melawan perkembangan kanker dan menunjukkan terjadinya peningkatan metastase [6]. Sedangkan perubahan diferensiasi sel ke arah pola yang tidak normal menunjukkan perubahan sel ke arah keganasan [7]. Berdasarkan hal tersebut parameter-parameter biologis tersebut dapat dinilai dengan cara mengukur frekuensi mitosis, frekuensi apoptosis, dan perubahan pola diferensiasi sel.

Saat ini sedang dikembangkan berbagai pengobatan baru yang diambil dari alam. Salah satunya adalah pengembangan berbagai penelitian mengenai khasiat dari spesies Curcuma (sebangsa kunyit). Tumbuhan golongan ini juga dikenal bermanfaat dalam pengobatan tradisional terhadap berbagai penyakit pada hepar. Penelitian terbaru diketahui bahwa bahan aktif dari berbagai spesies Curcuma tersebut adalah curcumin. Curcumin (diferuloylmethane) adalah pigmen kuning yang banyak didapatkan dari isolasi spesies Curcuma, Zingiberaceae [8]. Curcumin berupa senyawa polyphenolic dengan $\beta$-diketone moiety [9]. Curcumin disebutkan mempunyai aktifitas sebagai anti kanker, dan hingga kini penelitian mengenai hal ini masih dikembangkan $[3,8,10,11,12,13,14,15,16]$.

Penelitian ini bertujuan mengetahui efek pemberian curcumin terhadap perkembangan tumor yang diinduksi dengan benzapyrene, untuk mengetahui pengaruh pemberian curcumin pada perubahan frekuensi proliferasi (indeks proliferasi), frekuensi apoptosis (indeks apoptosis) dan perubahan pola differensiasi (N/C ratio) sel hepar pada perkembangan tumor hepar.

\section{METODE PENELITIAN}

Penelitian ini dilakukan dengan metode post test only design, pada hewan coba mencit $B A L B / C$ jantan, yang dilaksanakan di Laboratorium Farmakologi dan Laboratorium Biomedik, Fakultas Kedokteran, serta di Laboratorium Biologi Molekuler, Fakultas Matematika dan IImu Pengetahuan Alam, Universitas Brawijaya, Malang.

\section{Hewan Coba}

Penelitian menggunakan 20 ekor mencit (Mus musculus Outbred $B A L B / C$ ) jantan dari Pusvetma
Waru-Surabaya, dengan usia 5 minggu, yang terbagi menjadi 4 kelompok yaitu kelompok normal (kelompok 1), kelompok yang diberi injeksi corn oil (i.p) 3,2 ml tiap kgBB, tanpa BaP, tidak diberi curcumin dalam pakannya (kelompok 2), kelompok yang diberi injeksi BaP $16 \mathrm{mg}$ tiap kgBB dalam pelarut corn oil 3,2 ml tiap kgBB (i.p), tidak diberi curcumin (kelompok 3), kelompok yang diberi injeksi BaP $16 \mathrm{mg}$ tiap kgBB dalam pelarut corn oil 3,2 ml tiap $\mathrm{kgBB}$ (i.p), diberi 0,2\% curcumin dalam pakannya (kelompok 4)

Injeksi BaP dan Corn Oil

Injeksi dimulai pada minggu pertama (minggu ke-2, setelah aklimatisasi 1 minggu), dilakukan tiap minggu hingga minggu ke-12. Untuk kelompok 3 dan 4, dosis injeksi BaP adalah $16 \mathrm{mg}$ tiap kgBB. Injeksi BaP dilakukan dalam pelarut corn oil sebanyak $1 / 5$ dari angka yang didapatkan untuk dosis BaP (dalam $\mathrm{ml}$ ) atau sama dengan $3,2 \mathrm{ml}$ tiap kgBB. Cara perhitungan dosis corn oil ini diterapkan pula untuk kelompok 2 (Gambar 1).

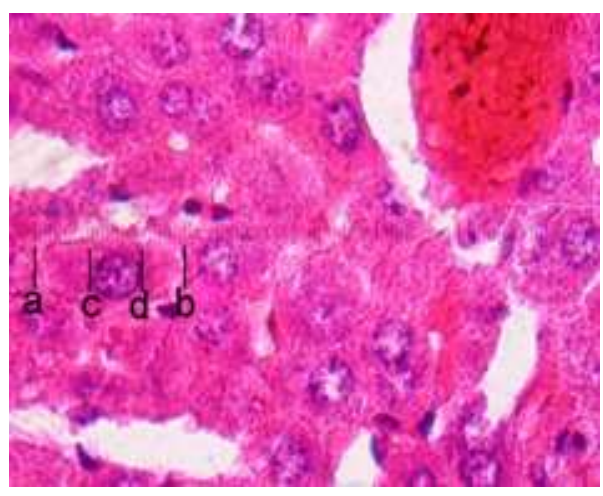

Gambar 1. Diameter nukleus (N) diukur dari garis c ke garis $\mathrm{d}$. Diameter sitoplasma (C) diukur dari garis a ke garis b. Diukur dengan mikrometer pada perbesaran 1000x.

\section{Pemberian Curcumin}

Khusus untuk kelompok 4, curcumin diberikan sejak hari pertama perlakuan, sejumlah $0,2 \%$ dari berat total seluruh makanan dan perlakuan lainnya sesuai dengan pembagian perlakuan.

\section{Pembuatan Sediaan (del) untuk Pemeriksaan Patologi Anatomi \\ Pada hari ke 120, mencit dimatikan,} kemudian diambil heparnya, lalu masing-masing dibuat dua slide, yang pertama dilakukan pengecatan immunohistokimia untuk mewarnai Cyclin-PCNA sel, slide kedua diberi pewarnaan hematoksillin eosin untuk pemeriksaan apoptosis dan diferensiasi. 


\section{Pemeriksaan Proliferasi}

Pemeriksaan proliferasi dilakukan dengan menghitung indeks Cyclin-PCNA, yaitu jumlah sel hepar yang mengekspresikan Cyclin-PCNA per 500 sel pada lapang pandang yang diambil secara acak pada perbesaran 400 kali [13]. PCNA (CyclinPCNA) adalah suatu protein inti dengan BM 36 kDa yang diekspresikan secara spesifik oleh semua sel yang sedang berproliferasi, yaitu pada fase G1 akhir dan fase $\mathrm{S}$ dalam siklus sel Pembuatan Slide Untuk Pemeriksaan Patologi Anatomi

Hari ke-120, mencit dimatikan kemudian diambil organ heparnya, lalu masing-masing dibuat dua slide, yang pertama dilakukan pengecatan immunohistokimia untuk mewarnai Cyclin-PCNA sel, slide kedua diberi pewarnaan hematoksillin eosin untuk pemeriksaan apoptosis dan diferensiasi.

\section{Pemeriksaan Apoptosis}

Pemeriksaan apoptosis dilakukan dengan menghitung indeks apoptosis, yaitu jumlah sel yang mengalami apoptosis per 500 sel hepar pada lapang pandang yang diambil secara acak, dan dilihat dengan mikroskop cahaya pada perbesaran 400 kali [13]. Menurut Sel apoptosis diidentifikasikan dengan pengecatan $\mathrm{HE}$, sebagai sel hepar yang menunjukkan shrinkage cell, nuclear condensation, dan apoptotic bodies formed $[6,13,17]$.

\section{Pemeriksaan differensiasi sel}

Pemeriksaan diferensiasi dilakukan dengan menghitung nucleus/citoplasma ratio ( $\mathrm{N} / \mathrm{C}$ ratio) dari 10-30 hepatosit. Diameter nukleus dan sitoplasma yang diukur adalah diameter yang terbesar dari sel tersebut, yang diukur dengan mikrometer dan dilihat dengan menggunakan mikroskop cahaya pada perbesaran 1000 kali [1]. Analisa Statistik

Data dianalisa dengan menggunakan metode ANOVA One-way. Perbedaan dinyatakan signifikan bila $\mathrm{p}<0,05$.

\section{HASIL DAN PEMBAHASAN}

Berdasarkan data hasil penelitian ini membuktikan bahwa curcumin yang diberikan pada periode inisiasi dan akhir inisiasi mampu menghambat karsinogenesis yang terjadi pada sel hepar mencit akibat paparan benzapyrene. Hal tersebut tampak dari adanya hambatan proliferasi yang berupa penurunan indeks PCNA (Tabel 1. dan Gambar 2.).

Peningkatan apoptosis ditunjukkan dengan adanya peningkatan indeks apoptosis (Tabel 2. dan Gambar 3.) dan perbaikan pola diferensiasi sel yang ditandai dengan penurunan $\mathrm{N} / \mathrm{C}$ ratio ke arah normal (Tabel 3. dan Gambar 4.) pada kelompok mencit yang diinduksi benzapyrene dengan ditambah pemberian 0,2\% curcumin dalam pakan (kelompok 4), dibanding dengan kelompok mencit dengan induksi benzapyrene tanpa tambahan curcumin dalam pakan (kelompok 3).

Tabel 1. Indeks Cyclin-PCNA dari hepatosit 4 kelompok hewan coba

\begin{tabular}{|c|c|}
\hline Kelompok & Indeks PCNA \\
\hline 1 (normal) & $25,9340 \pm$ \\
\hline $2(+c$ & 32,1080 \\
\hline $\mathrm{il},+\mathrm{BaP})$ & $50,5460 \pm$ \\
\hline ,+curcumin) & 38 \\
\hline \\
\hline \multirow{2}{*}{\multicolumn{2}{|c|}{$\begin{array}{l}\text { Data adalah rata-rata } \pm S D \\
\text { a : tidak berbeda bermak } \\
>0,05 \text { ) }\end{array}$}} \\
\hline & \\
\hline \multicolumn{2}{|c|}{$\begin{array}{l}>0,05) \\
\text { b : berbeda bermakna dengan kelompok } 2(p<0,01)\end{array}$} \\
\hline \multicolumn{2}{|c|}{$\begin{array}{l}\text { : berbeda bermakna dengan kelompok } 3(p<0,05) \\
\text { berbeda bermakna dengan kelompok } 1 \quad(p<0,05) \text {; } \\
\text { tidak berbeda bermakna dengan kelompok } 2(p>0,05)\end{array}$} \\
\hline
\end{tabular}

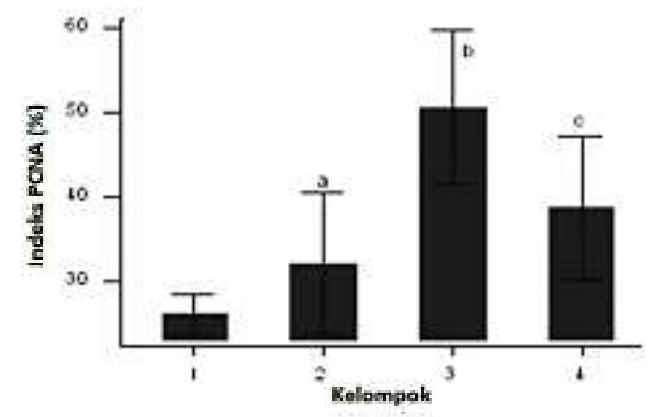

Gambar 2. Indeks Cyclin-PCNA dari hepatosit ke 4 kelompok hewan coba. Curcumin menurunkan indeks proliferasi hepatosit pada hewan coba yang dipapar dengan $\mathrm{BaP}$

Tabel 2. Indeks apoptosis dari hepatosit ke-4 kelompok hewan coba

\begin{tabular}{|c|c|}
\hline Kelompok & Indeks Apoptosis \\
\hline (normal) & \\
\hline (+corn oil) & $13,7840 \pm 2,23866^{a}$ \\
\hline (+corn oil, + BaP) & $1600 \pm 1$ \\
\hline$+\mathrm{BaP},+$ & \\
\hline \multicolumn{2}{|l|}{ keterangan: } \\
\hline \multicolumn{2}{|c|}{$\begin{array}{l}\text { Data adalah rata-rata } \pm \text { SD } \\
\text { a : tidak berbeda bermakna dengan kelompok } 1(p> \\
0,05) \\
\text { b : berbeda bermakna dengan kelompok } 2(p<0,01) \\
\text { c : berbeda bermakna dengan kelompok } 3(p<0,05) \text {; } \\
\text { berbeda bermakna dengan kelompok } 1 \quad(p<0,05) ; \\
\text { tidak berbeda bermakna dengan kelompok } 2(p>0,05)\end{array}$} \\
\hline
\end{tabular}

Kesetimbangan antara proliferasi, apoptosis, dan pola diferensiasi sel adalah tiga hal penting yang mempengaruhi pertumbuhan dari suatu 
tumor [19]. Hasil penelitian ini menambah bukti adanya potensi curcumin dalam pencegahan terjadinya neoplasma khususnya pada organ hepar, dan juga memberikan salah satu dasar ilmiah bagi pengobatan tradisional yang menggunakan tumbuhan species Curcuma (kunyit, curcumin adalah bahan aktif di dalamnya) untuk terapi neoplasma hepar.

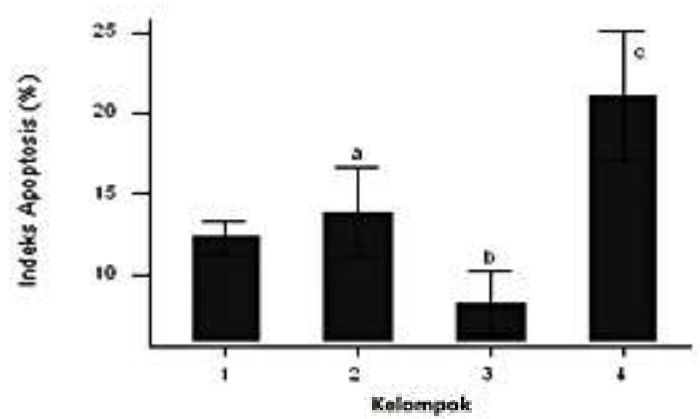

Gambar 3. Indeks apoptosis dari hepatosit ke-4 kelompok hewan coba. Curcumin meningkatkan indeks apoptosis hepatosit pada hewan coba yang dipapar dengan BaP

Hasil perhitungan N/C ratio hepatosit dari 4 kelompok mencit adalah sebagai berikut :

Tabel 3. N/C Ratio dari hepatosit ke-4 kelompok hewan coba

\begin{tabular}{ll}
\hline Kelompok & N/C ratio \\
\hline 1 (normal) & $0,3540 \pm 0,01817$ \\
2 (+corn oil) & $0,3560 \pm 0,02074^{a}$ \\
3 (+corn oil,+BaP) & $0,6080 \pm 0,02864^{b}$ \\
4 (+corn oil, + BaP,+curcumin) & $0,5180 \pm 0,02049^{c}$ \\
\hline keterangan: & \\
Data adalah rata-rata \pm SD & \\
a : tidak berbeda bermakna dengan kelompok $1(p>$ \\
o,05) \\
c : berbeda bermakna dengan kelompok $2(p<0,01)$ \\
: berbeda bermakna dengan kelompok $3(p<0,05) ;$ \\
berbeda bermakna dengan kelompok $1 \quad(p<0,05) ;$ \\
tidak berbeda bermakna dengan kelompok $2(p>0,05)$
\end{tabular}

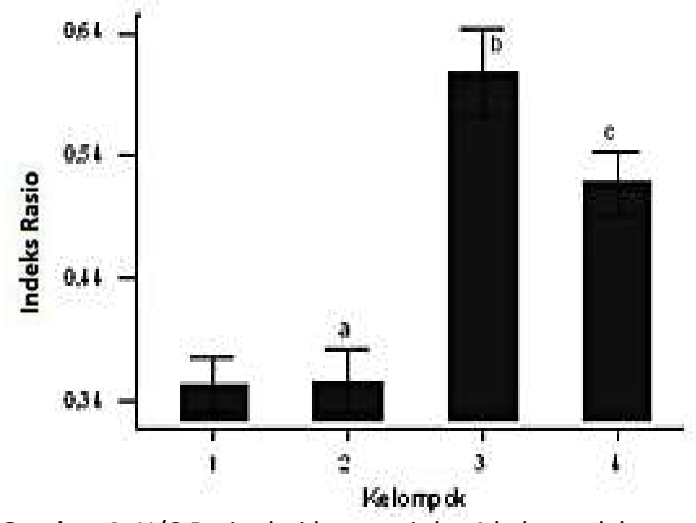

Gambar 4. N/C Ratio dari hepatosit ke-4 kelompok hewan coba. Curcumin menurunkan N/C ratio hepatosit pada hewan coba yang dipapar dengan $\mathrm{BaP}$.

\section{Hasil Proliferasi Sel}

Pengukuran proliferasi pada penelitian ini menggunakan indeks PCNA, berdasarkan hasil perhitungan tersebut diketahui bahwa curcumin $0,2 \%$ dalam pakan secara efektif dapat menghambat peningkatan indeks proliferasi pada mencit yang dipapar dengan benzapyrene. Hasil ini sesuai dengan penelitian yang telah dilakukan sebelumnya oleh Chuang et. al., (2000) [3]. Penelitian tersebut menjelaskan bahwa pemberian curcumin juga dapat mengembalikan kadar PCNA menuju ke arah normal. Hasil penelitian ini dan penelitian oleh Chuang et. al., (2000), diketahui bahwa curcumin sama-sama menurunkan kadar PCNA, walaupun metode yang digunakan berbeda, pada penelitian ini pemeriksaan PCNA dilakukan dengan immunohistokimia, sedang penelitian Chuang et. al., (2000) menggunakan metode Western blotting. Persamaan hasil ini memperkuat bukti adanya kemampuan curcumin dalam mempengaruhi protein khusus PCNA pada proses karsinogenesis yang terjadi pada mencit, bahkan meskipun proses karsinogenesisnya diinduksi dengan bahan karsinogen yang berbeda. Pada penelitian ini menggunakan benzapyrene sedangkan penelitian Chuang et. al., (2000) menggunakan diethylnitrosamine/DEN [3]. Aksi benzapyrene dalam menimbulkan karsinogenesis yaitu melalui mutasi yang terjadi akibat guanin terbaca sebagai timin (transversi). Hal ini sesuai dengan teori yang dikemukakan oleh King (2000) [5]. Tetapi, menurut Halliwell et al. (1998), mutasi pada BaP bukan hanya karena ikatan kovalen antara ultimate carcinogen dengan guanin, tapi juga akibat terbentuknya $\mathrm{O}_{2}{ }^{-}$radikal karena oksidasi metabolit BaP [18].

\section{Hasil Apoptosis Sel}

Pengaruh curcumin pada apoptosis sel dalam penelitian ini sesuai pula dengan hipotesis, yaitu pemberian curcumin $0,2 \%$ dalam pakan menyebabkan peningkatan sel apoptosis pada mencit yang dipapar dengan benzapyrene. Hasil ini konsisten dengan penelitian-penelitian sebelumnya yang dilakukan oleh Mahmoud et. al (2000) [11] dan Kawamori et al. (1999) [13] meskipun sel yang diamati berbeda. Persamaan hasil ini menunjukkan bahwa walaupun jenis sel yang diteliti berbeda, tetapi kemampuan curcumin dapat meningkatkan apoptosis adalah sama. Persamaan hasil dengan penelitian Kawamori et al., (1999) [13] semakin menguatkan bukti bahwa curcumin mungkin bekerja dengan cara yang sama sebagai anti kanker. Hal ini ditunjukkan dengan adanya 
peningkatan sel apoptosis pada mencit yang diinjeksi dengan benzapyrene, dan hal ini dapat dilihat dengan pemeriksaan yang lebih sederhana dengan pengecatan HE (Gambar 5.).
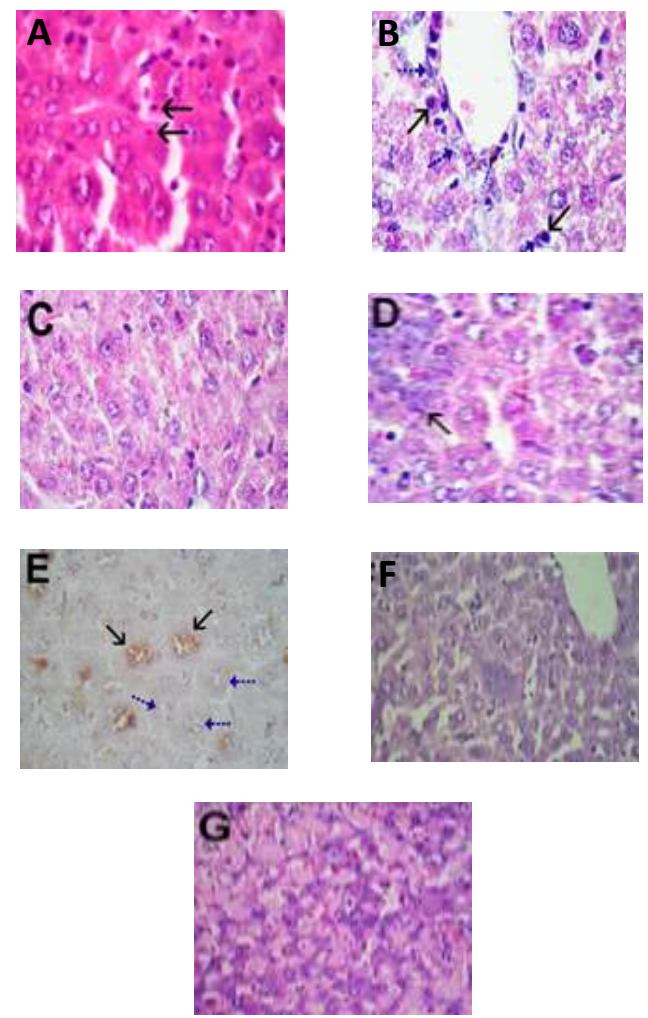

Gambar 5. Histopatologi Hepar dengan pewarnaan Hematoxillin-Eosin dan Immunohistokimia (1000x).

Keterangan:

A : Mencit normal, tampak hepatosit apoptosis yaitu sebagai councilman bodies

B : Mencit dengan injeksi corn oil Tampak hepatosit apoptosis, $(\uparrow)=$ sel $\mathrm{kupffer} /$ makrofag menandakan adanya proses fagositosis dalam eliminasi sel apoptosis

C : Mencit dengan injeksi BaP

D : Mencit dengan injeksi BaP dan diberi curcumin. Tampak kumpulan sel kupffer, $(\uparrow)=$ menunjukkan adanya peningkatan aktifitas fagositik sel kupffer pada pemberian curcumin

E : Mencit dengan injeksi corn oil (immunohistokimia). Tampak inti sel yang tercat positif dengan pengecatan immunohistokimia terhadap PCNA ( $\uparrow)$, dan tampak pula inti sel yang tercat negatif $(\uparrow)$

$\mathrm{F}$ : Mencit dengan injeksi BaP dan diberi curcumin (Hematoxillin-eosin,400x). Tampak ruang-ruang kosong akibat apoptosis yang meningkat.

$\mathrm{G}$ :Mencit dengan injeksi BaP dan diberi curcumin (Hematoxillin-eosin,400x). Tampak ruang-ruang kosong akibat apoptosis yang meningkat.

Dalam penelitian ini, pemberian curcumin $0,2 \%$ pada mencit jantan yang dipapar benzapyrene menyebabkan peningkatan indeks apoptosis yang sangat tinggi, bahkan melampaui indeks apoptosis mencit normal $(P<0,01)$. Walaupun terdapat peningkatan indeks proliferasi juga, tetapi tampaknya proliferasi tersebut kurang mengimbangi peningkatan apoptosis, sehingga tampak banyak ruang kosong diantara sel-sel hepatosit (Gambar 5). Hal ini karena dosis curcumin yang diberikan dalam penelitian ini $(0,2 \%$ dari total pakan) termasuk dosis tinggi, sesuai dengan penelitian Banjerdpongchai et al. (2002), pada penelitian tersebut pengaruh curcumin pada apoptosis tampak bergantung pada dosis yang diberikan. Penelitian tersebut menyatakan bahwa curcumin pada dosis rendah $(0,27 \mathrm{nM}-0,27 \mu \mathrm{M})$ dapat mencegah apoptosis sel HL60, sedangkan pada dosis yang lebih tinggi $(2,71-27,15 \mu \mathrm{M})$, curcumin bekerja secara sinergis dengan doxorubicin, menyebabkan apoptosis sel HL60 [19]. Hal ini sesuai dengan Banjerdpongchai et al., (2002) [19] dan Leu et al., (2002) [9] bahwa curcumin menunjukkan efek antioksidan maupun prooksidan, pada dosis rendah curcumin berperan dalam scavenger radikal bebas dan donasi elektron atau hidrogen, dan hal ini yang menyebabkan adanya efek protektif curcumin. Sedangkan efek prooksidan curcumin dapat terjadi karena adanya ion $\mathrm{Cu}(\mathrm{II})$, dengan adanya ion tersebut, curcumin dapat menyebabkan pembentukan reactive oxygen species (ROS) khususnya hydroxyl radical. Hal ini dapat terjadi karena struktur curcumin mengandung diferuloylmethane sebagai komposisi mayor dan beberapa derivat minor misalnya monomethoxycurcumin, demethoxy-curcumin, dan bisdemethoxycurcumin. Semua derivat tersebut mempunyai perlengkapan yang berbeda-beda sebagai aktifitas prooksidan dan antioksidan. Pada penelitian ini, ROS yang dihasilkan akibat pemberian $0,2 \%$ curcumin sangat tinggi, sehingga terjadi peningkatan apoptosis yang berlebihan dan mengakibatkan ruang-ruang kosong yang tidak diisi oleh sel hepar.

\section{Hasil Pola Diferensiasi Sel}

Selama ini, penelitian terhadap pengaruh curcumin pada pola differensiasi sel belum diperhatikan. Secara sederhana, peneliti memeriksa pola diferensiasi sel tersebut dengan cara mengukur nucleus/citoplasma (N/C) cell ratio. Hasil penelitian ini sesuai dengan hipotesis, dimana pemberian curcumin dapat memperbaiki pola diferensiasi sel, yang ditandai dengan adanya penurunan $\mathrm{N} / \mathrm{C}$ ratio yang bermakna 
pada hewan coba yang diinduksi benzapyrene dengan pemberian $0,2 \%$ curcumin dalam makanannya (kelompok 4) dibandingkan dengan hewan coba yang diinduksi benzapyrene tanpa pemberian curcumin (kelompok 3). Pada kelompok 3, N/C ratio meningkat mendekati 1 , menunjukkan adanya gangguan pola diferensiasi yang mengarah pada keganasan sel.

Cara Kerja Benzapyrene dalam Meningkatkan Proliferasi, Menurunkan Apoptosis dan Mengganggu Pola Differensiasi Sel

Pada teori yang dikemukakan Halliwel et al. (1998) [18] menyatakan bahwa di dalam tubuh, benzapyrene diubah menjadi 7,8-diol-9,10epoxide (ultimate carcinogene) oleh enzim sitokrom P-450, dan kemudian berikatan dengan guanin pada DNA, sehingga menimbulkan kerusakan pada DNA. Aktifitas peroksidase dari sintesis prostaglandin, myeloperoxidase, dan lactoperoxidase juga mengubah BaP menjadi 6hydroxybenzpyrene yang kemudian teroksidasi sehingga menjadi campuran quinone dengan menghasilkan $\mathrm{O}_{2}^{-}$radikal yang kemudian semakin menyebabkan kerusakan DNA. Kerusakan DNA disebabkan ikatan kovalen antara ultimate carcinogen atau ROS dengan DNA. Ikatan kovalen tersebut merusak struktur DNA, sehingga replikasi DNA terganggu. Jika kerusakan DNA terjadi pada gen suppressor tumor p53, maka menyebabkan mutan p53, sesuai dengan penelitian sebelumnya mengungkapkan bahwa secara normal bila terdapat kerusakan DNA, p53 normal (wild type) akan berperan dalam menghambat proliferasi, dan mendorong terjadinya repair DNA atau apoptosis $[5,17,20$, $21,22]$. Tetapi bila gen p53 mengalami mutasi (mutan p53), hal ini akan menghasilkan kegagalan perbaikan DNA, dan semakin mengakibatkan timbulnya mutasi DNA. Mutasi juga dapat terjadi pada gen yang terlibat dalam regulasi gen $\mathrm{p} 53$. Hal ini menyebabkan kegagalan fungsi p53 pula, sesuai dengan teori Chumakov (2000) [23].

Jika mutasi terjadi pada proto-onkogen, seperti yang dinyatakan oleh Sukardja (2000) [1], maka akan menyebabkan perubahan protoonkogen menjadi onkogen yang selanjutnya mengkode pembuatan peptida yang bersifat pertumbuhan. Selain itu, aktifitas dari beberapa protein sinyal transduksi juga diubah oleh ROS, yaitu tyrosine phosphatase, mitogen-activated protein kinase, NF- $\mathrm{KB}$, dan AP-1, dimana efek dari oksidasi oleh ROS tersebut mengakibatkan peningkatan transkripsi dan bersifat mitogenik, sesuai dengan teori King (2000) [5].

\section{Cara Kerja Curcumin dalam Menghambat Peningkatan Proliferasi dan Memperbaiki Pola Diferensiasi Sel}

Aksi kemopreventif curcumin melawan benzapyrene yaitu dengan kemampuan aktifitas metabolik, seluler dan molekuler curcumin yang luas. Leu et al. (2002) menjelaskan bahwa curcumin bekerja sebagai pengganti karsinogen (dalam penelitian ini adalah BaP) untuk menjadi ligan bagi Aryl Hydrocarbon Receptor (AHR), yaitu reseptor bagi enzim detoksifikasi, atau bahkan bekerja menghambat berbagai isoenzim sitokrom P450, sehingga BaP sebagai pro-karsinogen tidak diubah menjadi ultimate karsinogen [9].

Curcumin juga berperan sebagai scavenger bagi radikal bebas dan meningkatkan ekspresi glutathione S-transferase (GST) hepar, sesuai dengan pendapat beberapa peneliti lain $[8,9$, 24]. Hal ini menyebabkan hambatan pada kerusakan DNA akibat radikal bebas yang terbentuk karena oksidasi 6-hydroxybenzpyrene, salah satu metabolit BaP. Titik kerja curcumin yang lain adalah pada hambatan sintesis DNA dan RNA yang mengakibatkan hambatan proliferasi, sesuai dengan penelitian yang dilakukan oleh Huang et al. (1997) [15].

Beberapa penelitian lain dijelaskan bahwa dalam efek anti proliferatif, curcumin juga menekan ekspresi c-jun melalui hambatan pada c-Jun N-Terminal Kinase (JNK), dan menekan ekspresi c-fos melalui hambatan pada extracellular signal-regulated protein kinase (ERK) sehingga mempunyai efek inhibisi pada aktifitas Activator Protein-1 (AP-1), yang berakibat menghambat aktifitas enzim Ornithine decarboxylase (ODC) dan menurunkan kadar mRNA ODC $[8,9,16]$.

Curcumin juga dapat menghambat aktifitas faktor transkripsi NF- $\mathrm{B}$, dengan cara menghambat fosforilasi dan degradasi $І$ $\kappa B$ serta mengganggu aktifasi IKB kinase (IKK), sesuai dengan teori beberapa peneliti sebelumnya $[9,25,26]$. Hambatan pada AP-1 dan NF-кB mengakibatkan inhibisi Galectin-3. Galectin 3 adalah suatu lectin 32 kD yang secara spesifik mengenali struktur galaktosida dari glikan, dan berperan penting pada berbagai proses biologis. Lokasi galectin 3 adalah di dalam nukleus, sitoplasma, pada membran sel dan dalam matriks ekstraselular, dengan menunjukkan fungsi berbeda-beda, termasuk mengubah sifat adesi sel dan mengatur motilitas sel. Galectin-3 
menunjukkan sifat anti apoptosis, meningkatkan pertumbuhan, dan meningkatkan kemampuan invasi sel [27]. Teori yang dikemukakan oleh beberapa peneliti hambatan pada AP-1 dan NF$\kappa B$ juga menyebabkan inhibisi aktifitas enzim iNOS dan inhibisi transkripsi gen dan aktifitas enzim COX-2 $[9,14]$. Curcumin juga berperan dalam inhibisi ekspresi oncoprotein $\beta$-catenin, suatu komponen dari adherent junction pada sel epitel intestinal dan berperan penting pada komunikasi interselular dan migrasi sel [11].

Curcumin juga menyebabkan inhibisi pada berbagai protein lain yang terlibat dalam proliferasi, termasuk Protein Kinase C (PKC)), PCNA, p21, CDC2, dan epidermal growth factor receptor (EGFR) Tyrosine Kinase (termasuk p $185^{\text {neu }}$ ). Hambatan pada Protein Kinase C (PKC) dan protein tyrosine kinase menyebabkan hambatan aktifasi transkripsi dari Early Growth Response Gene Product (Egr-1) [3,9,12].

\section{Cara Kerja Curcumin dalam Meningkatkan Apoptosis Sel}

Curcumin menyebabkan peningkatan apoptosis dengan berbagai cara, antara lain dengan meningkatkan pembentukan reactive oxygen species khususnya hydroxyl radical, seperti telah dijelaskan sebelumnya [19]. Stres oksidatif akibat ROS yang terbentuk ini kemudian menyebabkan pelepasan sitokrom c dari mitokondria, yang lebih jauh menimbulkan aktifasi pro-caspase 3 dan fragmentasi DNA. Selanjutnya menyebabkan terjadinya kematian sel melalui apoptosis [28].

Selain itu, kemampuan curcumin dalam meningkatkan apoptosis berhubungan dengan efek inhibisi curcumin pada NF- $\kappa$ B. Inhibisi pada NF-KB menyebabkan peningkatan apoptosis, karena adanya persamaan agen yang menginduksi (misalnya TNF- $\alpha$ ), meskipun hal ini belum pasti kejelasannya. Menurut Dumic et al. (2002) [27], mekanisme NF-KB dalam memblok apoptosis disebabkan pula oleh adanya hubungan antara NF-KB dengan galektin-3, protein yang mempunyai sifat anti apoptosis. Jadi adanya hambatan pada NF-KB akibat pemberian curcumin menyebabkan galektin-3 terhambat, sehingga terjadi peningkatan apoptosis.

Curcumin juga menyebabkan peningkatan apoptosis melalui penurunan bcl-xL, protein yang berfungsi menghambat apoptosis dengan mengikat dan mengasingkan bax. Selain itu, curcumin juga dapat menghambat Akt, suatu protein kinase yang menyebabkan ketahanan sel melalui hambatan pada apoptosis, yaitu dengan cara memfosforilasi bad sehingga terjadi pelepasan bcl-2 dan menghambat proses apoptosis. Selain itu, mekanisme curcumin dalam meningkatkan apoptosis adalah melalui penurunan ekspresi IAP. IAP merupakan protein yang dapat menghambat apoptosis melalui fungsinya sebagai inhibitor langsung dari caspase efektor teraktifasi, caspase 3 dan caspase 7, serta sebagai penghambat aktifasi caspase 9 yang diinduksi oleh sitokrom c [28].

\section{KESIMPULAN DAN SARAN \\ Kesimpulan}

Pemberian curcumin sebanyak 0,2\% dalam pakan selama periode inisiasi dan post inisiasi dapat menghambat peningkatan ekspresi PCNA, meningkatkan apoptosis, dan memperbaiki pola diferensiasi hepatosit yang dipapar dengan benzapyrene serta curcumin. Curcumin mempunyai kemampuan dalam menghambat karsinogenesis yang terjadi pada hepatosit mencit akibat paparan benzapyrene.

\section{Saran}

Perlu dilakukan penelitian tentang pengaruh curcumin pada fungsi hepar, dan penelitian yang melibatkan berbagai dosis curcumin untuk mendapatkan dosis optimal dalam menghambat karsinogenesis hepatosit. Perlu dilakukan penelitian mengenai pengaruh curcumin terhadap jenis-jenis sel lain atau sel yang berasal dari organ lain dan mekanisme kerja curcumin terhadap tubuh.

\section{DAFTAR PUSTAKA}

1. Sukardja, IDE. 2000. Onkologi Klinik edisi 2. Airlangga University Press. Surabaya

2. Grisham, J.W. 1996. Interspecies comparison of liver carcinogenesis: implications of cancer risk assessment.Carcinogenesis, 18(1): 59-81

3. Chuang, S.E., Cheng, A.L., Lin, J.K., and Kuo, M.L. 2000. Inhibition by Curcumin of diethylnitrosamine-induced hepatic hyperplasia, inflammation, cellular gene product and cell-cyclerelated protein in rats. Food and Chemical Toxicology, 38:991-995

4. Wang, $Y$, et al. 1997. Public Health Goal for Benzo(a)pyrene in Drinking Water. (http: //www.oehha.ca.gov/water/phg/pdf/bap_c.pdf). Tanggal akses 17 Desember 2003

5. King, R.J.B. 2000. Cancer Biology. Prentice Hall Pearson Education. New York.

6. Lyng,H., et al. 2000. Disease Control of Uterine Cervical Cancer: Relationships to Tumor Oxygen Tension, Vascular Density, Cell Density, and Frequency of Mitosis and Apoptosis Measured before Treatment and during radiotherapy. Clin. Cancer Res, 6:1104-1112 
7. Damjanov, I., et al. 1996. Histopathology. A Color Atlas and Textbook. Williams and Wilkins

8. Lin, JK., Shiau, SYL. (2001). Mechanisms of Cancer Chemopreventive by Curcumin. Proc. Natl. Sci. Counc. $R O C(B), 25: 59-66$

9. Leu, T.H., et al. 2002. The Molecular Mechanisms for the Antitumorigenic Effect of Curcumin. Curr. Med. Chem. - Anti-Cancer Agent,. 2:357-370

10. Perkins S, et al. 2002. Chemopreventive Efficacy and Pharmacokinetics of Curcumin in the Min/+ Mouse, a Model of Familial Adenomatous Polyposis. Cancer Epidemiology, Biomarkers \& Prevention, 11:535-540

11. Mahmoud, NN., et al. 2000. Plant phenolics decrease intestinal tumors in an animal model of familial adenomatous polyposis. Carcinogenesis, 21:921-927

12. Hong, RL., et al. 1999. Curcumin Inhibits Tyrosine Kinase Activity of $\mathrm{p} 185^{\text {neu }}$ and Also Depletes p185 $5^{\text {neu1 }}$. Clin Cancer Res, 5:1884-1891

13. Kawamori, T., et al. 1999. Chemopreventive Effect of Curcumin, a Naturally Occuring AntiInflammatory Agent, during the Promotion/Progression Stages of Colon Cancer. Cancer Res, 59:597-601

14. Zhang, F., et al. 1999. Curcumin inhibits cyclooxygenase-2 transcription in bile acid- and phorbol ester-treated human gastrointestinal epithelial cells. Carcinogenesis, 20:445-451

15. Huang, MT., et al. 1997. Inhibitory effects of topical application of low doses of curcumin on 12O-tetradecanoylphorbol-13-acetate-induced tumor promotion and oxidized DNA bases in mouse epidermis. Carcinogenesis, 18:83-88

16. Lu, Y.P., et al. 1994. Effect of curcumin on 12-Otetradecanoylphorbol-13-acetate- and ultraviolet B light-induced ex pression of c-Jun and c-Fos in JB6 cells and in mouse epidermis. Carcinogenesis, 15:2363-2370

17. Halliwel, B., Gutteridge, JMC. 1998. Free Radicals in Biology and Medicine, $3^{\text {rd }}$ ed. Oxford University Press

18. Wong, KMT., et al. 2002. Lung-Specific Expression of Dominant-Negative Mutant p53 in Transgenic Mice Increases Spontaneous and Benzo[a]pyreneInduced Lung Cancer. Am.J.Respir. Cell Mol.Biol, 26:186-193

19. Banjerdpongchai, R., et al. 2002. Effect of Curcumin on HL60 Cell Apoptosis Induced by Doxorubicin. Chiang Mai Med Bull. 41(2):59-66

20. Yoon, JH, et al. 2001. Methylated CpG Dinucleotides Are the Preferential Targets for G-to$\mathrm{T}$ Transversion Mutations Induced by Benzo[a]pyrene Diol Epoxide in Mammalian Cells: Similarities with the p53 Mutation Spectrum in Smoking-associated Lung Cancer. Cancer Res, 61:7110-7117

21. Smith, LE., et al. 2000. Targeting of Lung Cancer Mutational Hotspots by Polycyclic Aromatic Hydrocarbons. J of the National Cancer Institute, 92:803-811
22. Denissenko, M.F., et al. 1996. Preferential Formation of Benzo[a]pyrene Adducts at Lung Cancer Mutational Hotspots in p53. Science (Washington DC), 274:430-432

23. Chumakov, P.M. 2000. Function of the p53 Gene: Choice between Life and Death. Biochemistry (Moscow), 65 (1):28-40.

24. Balasubramanyam, M., et al. 2003. Curcumininduced inhibition of cellular reactive oxygen species generation : Novel therapeutic implications. J. Biosci. 28 715-721

25. Bharti, A.C., et al. 2003. Curcumin (diferuloylmethane) down-regulates the constitutive activation of nuclear factor $-\kappa B$ and $I \kappa B \alpha$ kinase in human multiple myeloma cells, leading to suppression of proliferation and induction of apoptosis. Blood, 101:1053-1062

26. Jobin, C., et al. 1999. Curcumin Blocks CytokineMediated NF-kB Activation and Proinflammatory Gene Expression by Inhibiting Inhibitory Factor I-kB Kinase Activity. The Journal of Immunology, 163: 3474-3483.

27. Dumic, J., et al. 2002. Curcumin - A Potent Inhibitor of Galectin-3 Expression. Food Technol. Biotechnol. 40 (4) 281-287

28. Woo, J.H., Kim, Y.H., Choi, Y.J., Kim, D.G., Lee, K.S., Bae,J.H., Min, D.S., Chang, J.S., Jeong, Y.J., et al., 2003. Molecular mechanisms of curcumin-induced cytotoxicity: induction of apoptosis through generation of reactive oxygen species, down regulation of $\mathrm{Bcl}-\mathrm{XL}$ and $\mathrm{IAP}$, the release of cytochrome $\mathrm{c}$ and inhibition of Akt. Carcinogenesis, 24(7):1199-1208. [doi:10.1093/ carcin/bgg082] 